TECHNICAL TRANSACTIONS 1/2017

CZASOPISMO TECHNICZNE $1 / 2017$

CIVIL ENGINEERING

DOI: $10.4467 / 2353737$ XCT.17.006.6103

\author{
Łukasz Łukaszewski (1lukaszewski@pk.edu.pl) \\ Institute of Building Materials and Structures, Faculty of Civil Engineering, Cracow \\ University of Technology
}

\title{
THE LASER SCANNING IN THE DIGITIZATION PROCESS \\ OF RELICTUALLY PRESERVED ARCHITECTURAL DETAILS
}

\section{SKANING LASEROWY W PROCESIE DIGITALIZACJI RELIKTOWO ZACHOWANYCH DETALI ARCHITEKTONICZNYCH}

\begin{abstract}
Protection of cultural heritage in recent times is of a very important significance. The priority task is to secure the existing facilities in such a way that they can now and in the future serve as a representations of the areas and be a treasure house of knowledge for both current and future generations. Through the development of new technologies and applying them by maintenance staff and those working to protect the national heritage, digitization has become widespread. Photogrammetry and laser scanning proved to be useful tools in a non-invasive process of heritage digitizing. In the article the author describes the process of creating a three-dimensional model of an architectural detail, the model of "acanthus leaf" which is the final product of the study. The methodology described by the author outlines the problems occurring during the measurement and subsequent data processing stages. The final product is an important database, useful when creating the reconstruction and renovation of similar facilities.
\end{abstract}

Keywords: cloud points, digitizing, 3D model, relic, reconstruction, laser scanning, virtual cave

\section{Streszczenie}

Ochrona dziedzictwa kulturowego w aktualnych czasach ma bardzo ważne znaczenie. Priorytetowym jej zadaniem jest zabezpieczenie istniejących obiektów w taki sposób, aby mogly one teraz i w przyszłości pełnić funkcję reprezentacyjną danych obszarów oraz być skarbnicą wiedzy dla aktualnych i przyszłych pokoleń. Poprzez rozwój nowych technologii i zastosowanie ich przez konserwatorów oraz osoby zajmujące się ochroną dziedzictwa narodowego cyfryzacja stała się powszechna. Fotogrametria oraz skaning laserowy okazały się przydatnymi narzędziami w nieinwazyjnym procesie digitalizowania dziedzictwa narodowego. $\mathrm{W}$ artykule autor opisuje proces tworzenia trójwymiarowego modelu wybranego detalu architektonicznego, modelu „liścia akantu”, który jest produktem finalnym badania. Metodologia opisana przez autora przedstawia problemy występujące podczas wykonywania pomiaru i w kolejnych etapach obróbki danych. Produkt finalny jest ważną bazą danych, przydatną podczas tworzenia rekonstrukcji i renowacji podobnych obiektów.

Słowa kluczowe: chmura punktów, digitalizacja, model 3D, relikt, rekonstrukcja, skaning laserowy, wirtualna jaskinia 


\section{Introduction}

A digitalization of relictually preserved architectural details resulted in the creation of a new branch of science based on promotion of knowledge and history. By creating interactive databases and then making them available on the Internet (via network) they provided an opportunity to conduct research on given objects to researchers from around the world. Thanks to the further verification of written sources and creating 3D models we can deeper and easier interpret and understand tested subjects. Three-dimensional reconstructions of movable and immovable monuments made in various academic as well as in scientific and research centers, despite the use of different methods and various degrees of advanced computer technology, are based on the principles of the Charter of London [1]. Most projects made by means of a laser scanner - both geodetic and triangulate - may also be used in museology and promoting knowledge for the purposes of popular scientific studies.

When the virtual reality (VR) [2] technology was developed, it has been fully absorbed by the field of cultural heritage for different purposes. Securing, protecting and reconstructing relictually preserved details required accurate and consistent approaches of behavior, analysis, and monitoring of their integrity for future generations. The documentation presented in numerical form of $\mathrm{CAD}$ and digital one was stored in the form of raster and vector files. Fast development of software also meant that printing the paper documentation has become a digital copy of the studies, of a much smaller utility value than the digital form [3].

Computer methods, apart from changing the form of the classic documentation have led to the emergence of new forms of documentation previously impossible to share or use. There appeared the possibility of relatively easy development of interactive, spatial presentation of objects and the use of digital, photogrammetric, semi-finished products as a source of metric information about the product. BIM technology development has also contributed to a simpler and broader use of the products generated from point clouds and with TIN grids widely used in reconstructing, architectural details by using $3 \mathrm{D}$ printers and interactive caves.

This article presents a methodology that can be used in a wide range of digitization and restoration work.

\section{Methodology}

\subsection{Equipment used}

In order to create an interactive 3D model of the "acanthus leaf" the author used the following equipment and specialized software:

A triangulation scanner with a matrix of $10 \mathrm{MPx}$ by Smarttech company,

A program enabling scanner support Mesh3Dx64,

A program for joining, editing point clouds Geomagic Studio 2014 x64,

A program for processing TIN model Autodesk 3ds Max Design 2015,

A program for publications Adobe Acrobat 3D PDF. 


\subsection{Measuring the object}

The first step to create a virtual model was a correct location of the object in relation to the scanner (Fig. 1). Through a complicated geometry of an object scanning process was repeatedly carried out for 45 times since the stereoscopic positioning

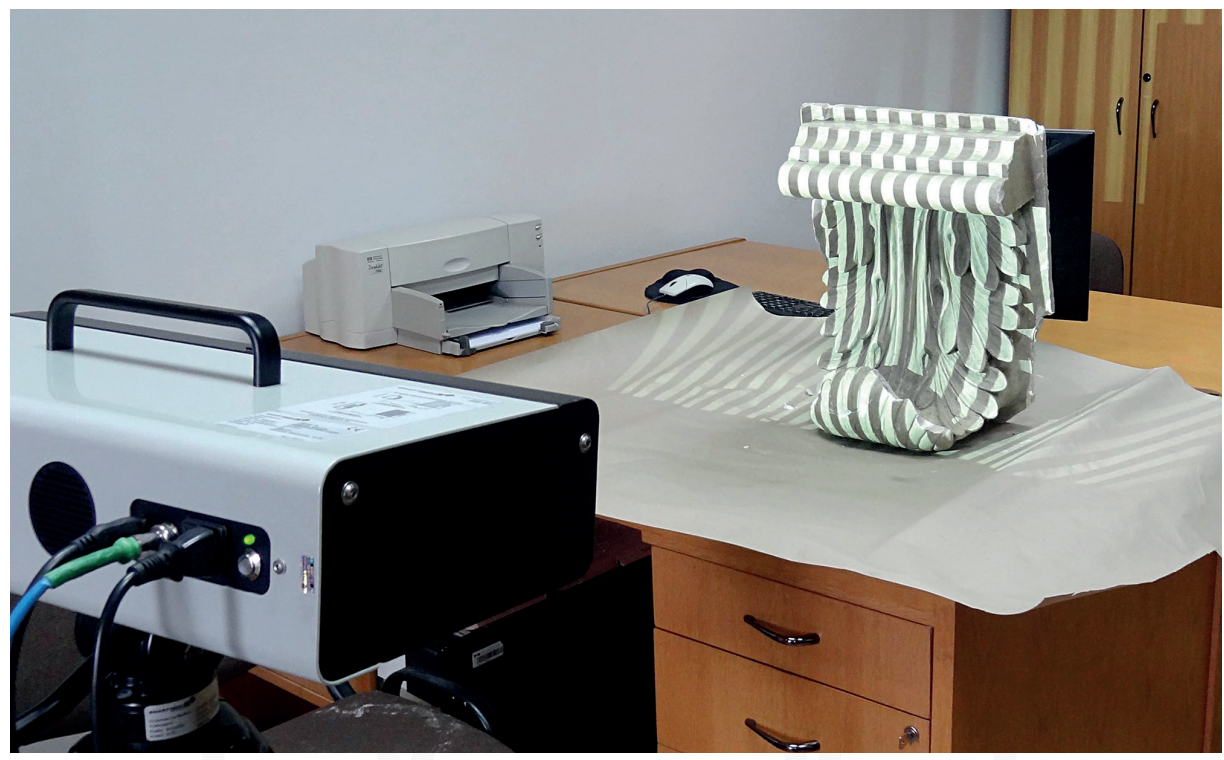

Fig. 1. Image of object measurement and positioning of the scanner

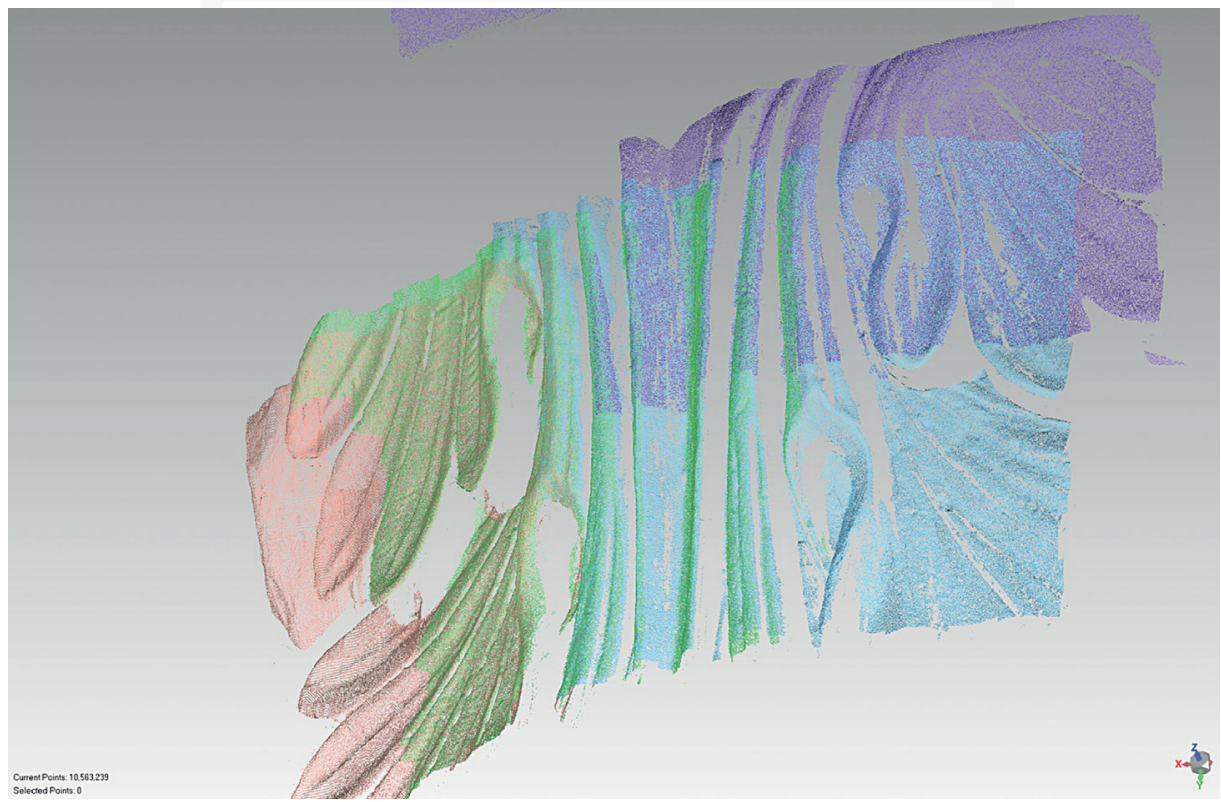

Fig. 2. Measuring divergences. Resulting from the geometry of the object 


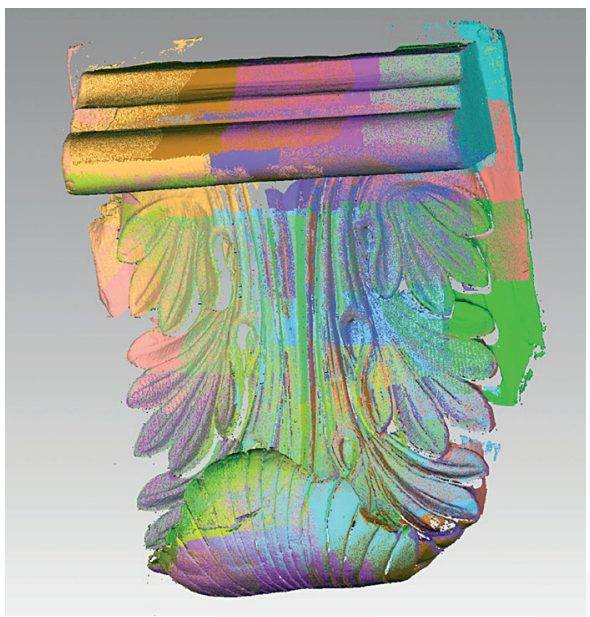

Fig. 3. The combined point clouds

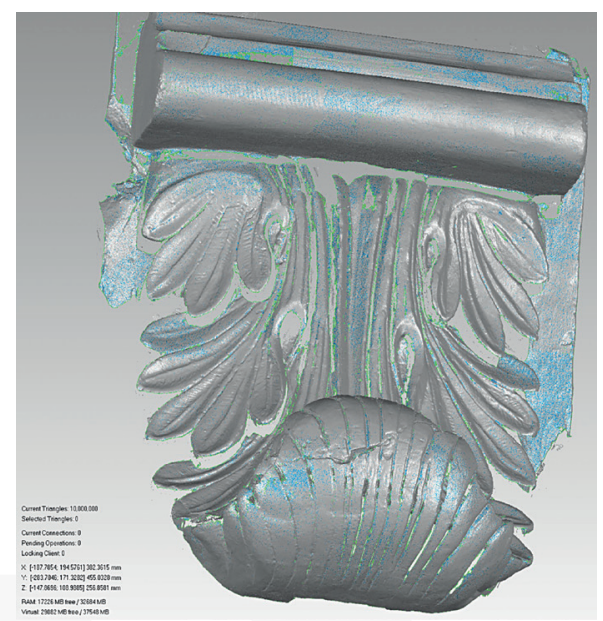

Fig. 4. The generated TIN grid

of the measuring elements in the scanner resulted in inaccuracies in the individual measurements (Fig. 2).

After obtaining point clouds, their appropriate number was selected and there were 35 elements left to easily combine in A sequence in the program of Geomagic Studio 2014 x64. After cleaning, generated clouds were arranged and a cloud numbering 66941225 pts. was obtained (Fig. 3).

The next step in the process of generating a 3D model was to create a grid TIN (Fig. 4) allowing easy correlations with other environmental graphic programs. Then in the program $3 \mathrm{ds}$ Max Design a finished product was rendered already with the applied texture. The finished product was made available in $3 \mathrm{D} \mathrm{PDF}$ format.

Table 1. A table containing the most important parameters of the study performed

\begin{tabular}{|c|c|c|}
\hline Scanner type & \multicolumn{2}{|c|}{ Triangulation, white light, 166 point on $1 \mathrm{~mm}^{2}$} \\
\hline Scanner volume & \multicolumn{2}{|c|}{$200(\mathrm{~mm}) \times 300(\mathrm{~mm}) \times 150(\mathrm{~mm})$} \\
\hline Number of completed scans & 45 & - \\
\hline Number of used scans & 35 & 66941225 pts. \\
\hline Number of generated triangles & \multicolumn{2}{|c|}{10000000} \\
\hline Time of measurment & \multicolumn{2}{|c|}{$3 \mathrm{~h}$} \\
\hline The duration of data processing & \multicolumn{2}{|c|}{$\mathrm{h}$} \\
\hline
\end{tabular}

\subsection{Problems encountered during the test}

During the measurement with triangulation scanner and data processing the author noted that there may be problems in the process of creating an interactive 3D model.

During the research we should pay attention to:

- adequate light put on the tested object, 
- the expected accuracy of the tested object in order to edit the cloud point where possible at a later stage,

- after each scan, check the quality and range of information of your interest,

- try to combine and analyze the scans done up to date so that after leaving the site of research one would not discover that something is missing or badly scanned,

- pay attention to metal surfaces and highly polished ones as some scanners do not read such surfaces,

- when connecting individual cloud points of measurement, pay attention to the redundant elements and emerging "noise",

- if necessary, take advantage of the program enabling cleaning point clouds to reduce their numbers,

- the ability to generate TIN grids by selecting the appropriate function:

$\triangleright$ with rounded transitions between vertices,

$\triangleright$ with sharp transitions between vertices.

\section{Conclusions}

To summarize you can draw conclusions from the digitization process of national heritage relics:

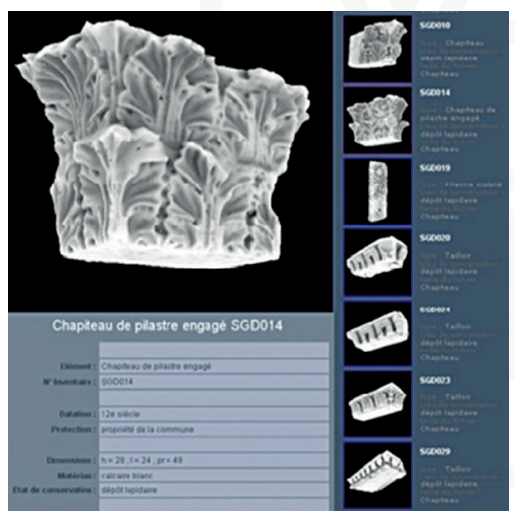

Fig. 5. Database of relics details digitized in $3 \mathrm{D}[7]$

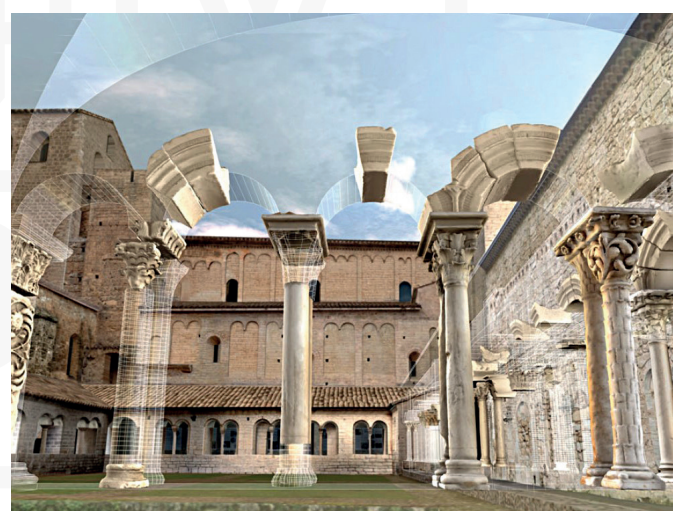

Fig. 6. The virtual presentation of the usage of digitized details [7]

1) effectiveness and time spent to scan and execution of the entire $3 \mathrm{D}$ model is relatively faster and easier compared to traditional methods of documenting relics [4]. Through the process of digitization you can create an interactive database of architectural details used in further research projects [5-7] (Fig. 5).

2) the possibility of spreading science with the development of cyber-technology, which streamlines the process of researching and non-invasive exploring of test items. It is worth to quote the words of Professor Andrzej Kadłuczka: “(...) the CAD environment can be applied to the needs of archiving and data processing about the object, and then for modeling its spatial reconstruction, verification without restric- 
tions and without harming the material substance (...)" [1]. Professor Karel Pavelka: „(..) reconstruction possibilities based on close-range photogrammetry in an image based modeling form or professional laser scanning and 3D printing using rapid prototyping technology. Thanks to low-cost and easy-to-use technology we are able to produce scaled 3D virtual models or real prints, which can be included with objects in any virtual museum $(\ldots)$ " [8].

3) the measurements form the basis for future analysis and comparison of measurements made in other technologies which will enable to verify the usability of the tools used in the process of digitization.

\section{References}

[1] Kadłuczka A., Rekonstrukcja architektoniczna - realne czy wirtualne modelowanie rzeczywistości historycznej?, Doktryny i Realizacje Konserwatorskie w Świetle Doświadczeń Krakowskich Ostatnich 30 lat, WAM, Kraków 2011, 209-223.

[2] Bruno F., Bruno S., De Sensi G., Luchi M., Mancuso S., Muzzupappa M., From 3D reconstruction to virtual realisty: A complete methodology of digital archeological exhibition, Journal of Cultural Heritage, Vol. 11, 2010, 42-49.

[3] Boroń A., Rzonca A., Wróbel A., Metody fotogrametrii cyfrowej i skanowania laserowego w inwentaryzacji zabytków, Roczniki Geometryki, Vol. V, Issue 8, 2007, 129-140.

[4] Markiewicz M., Cyfrowe techniki dokumentacji zabytków ruchomych na przykładzie halsztackiej ceramiki malowanej z Domasławia, gm. Kobiarzyce, Digitalizacja Dziedzictwa Archeologicznego - wybrane zagadnienia, Uniwersytet Kardynała Stefana Wyszyńskiego w Warszawie, Lublin 2011, 158-172.

[5] Pires H., Ortiz P., Marques P., Sanchez H., Close-range Lase Scanning Applied to Archeological Artifacts Documentation. Virtual Reconstruction of an XVIth Century Ceramic Pot, The 7th International Symphosium on Virtual Reality, Archaeology and Cultural Heritage VAST, 2006.

[6] Luis Lerma J., Muir C., Evaluating the 3D documentation of an early Christian upringht stone withc carvings from Scotlande witch multiples images, Journal of Archaeological Science, Vol. 46, 2014, 311-318.

[7] De Luca L., Methods, formalism and tool for the semantic-based surveying and representation of architectural heritage, Societe Italian di Fotogrammetria e Topgrafia 2011, online: 15.12.2011.

[8] Pavelka K., Sedina J., Faltynova M., Matouskova E., Documentation, 3D modeling and replication of archaeological artifacts, Processdings of the international Multidisciplinary Scientific GeoConferences SGEM, 2015, Vol. 4, 109-116. 